\title{
Adaptative processes, control measures, genetic background, and resilience of malaria vectors and environmental changes in the Amazon region
}

\author{
W. P. Tadei $\cdot$ I. B. Rodrigues $\cdot$ M. S. Rafael $\cdot$ R. T. M. Sampaio $\cdot$ \\ H. G. Mesquita - V. C. S. Pinheiro - J. A. C. Zequi - R. A. Roque • \\ J. M. M. dos Santos
}

Received: 16 July 2015/Revised: 16 July 2015/Accepted: 20 August 2016/Published online: 22 September 2016

(C) Springer International Publishing Switzerland 2016

\begin{abstract}
This study relates multiple parameters that are involved in the occurrence and control of malaria in the Amazon. Ebbs and floods, black and white waters, fishponds, and "repiquete" (Amazonian waters phenomenon) influence the density of Anopheles darlingi Root, 1926. The adaptive processes, genetic background, and resilience of Anopheles vectors change in response to climate and environmental changes. This study covers the diversity of anophelines, which increases due to anthropic activities. Regarding strategies for vector control, the following measures are important: (1) use mechanical barriers inside houses (screens and impregnated mosquito nets), (2) determine the level of anopheline resistance to insecticides, and (3) determine the effect
\end{abstract}

Guest editors: Adalberto L. Val, Gudrun De Boeck \& Sidinei M. Thomaz / Adaptation of Aquatic Biota of the Amazon

W. P. Tadei $(\varangle)$. I. B. Rodrigues ·

M. S. Rafael · R. T. M. Sampaio - H. G. Mesquita .

J. A. C. Zequi - R. A. Roque · J. M. M. dos Santos

National Institute of Amazonian Research, Ministry of

Science, Technology and Innovation, Coordination

Society, Environment and Health, Avenue André Araújo,

2936, Aleixo, Caixa-post:. 478, Manaus,

Amazonas 69083000, Brazil

e-mail: tadei@inpa.gov.br

V. C. S. Pinheiro

Center for Advanced Studies Caxias, Department of Chemistry and Biology, Maranhão State University, Street of Morro do Alecrim, Morro do Alecrim, Caxias,

Maranhão 65604380, Brazil of the physiological state of females on malaria transmission effectiveness. Bioinsecticides were found to be efficient in the control of immatures, and there was no alteration of the associated fauna. Data on genetic variability and vector populations demonstrated greater polymorphism in intradomicile subpopulations. Furthermore, knowledge on the structural genome and transcriptome of $A$. darlingi, associated with bio-ecology and evolution, may indicate an adaptive strategy of this species to the Amazon biome. There are anthropic activities and environmental and climatic changes that favor increased vector density, requiring specific control strategies to reduce populations of this species.

Keywords Amazon ecosystem - Anopheles darlingi . Brazilian malaria - Genetic variability . Vector control

\section{Introduction}

The Amazon Basin is home to some $40 \%$ of the world's remaining tropical forests and contains one of the Earth's richest assortments of biodiversity: thousands of species of plants, over one million insect species, more than 700 fish species, approximately 1,000 bird species, and over 300 mammalian species (Ministério do Meio Ambiente, 2010). The reduction of tropical forest areas, especially in tropical rainforests, will 
probably result in the loss of many species (Scholze et al., 2005). Climate change affects the Amazon region, which in turn is expected to alter the global climate and increase the risk of biodiversity loss (World Wide Fund, WWF, 2006). By 2050, along with a projected surface temperature increase of $2^{\circ} \mathrm{C}$, severe species loss is predicted across central Brazil and Mexico and in dry areas of Argentina, Bolivia, and Chile (Siqueira \& Peterson, 2003; Miles et al., 2004; Thomas et al., 2004). The central-eastern Amazon is predicted to undergo an irreversible process of "savannization" (Nobre et al., 2004; United Nations Framework Convention of Climate Change, UNFCCC, 2007).

Human activities in the Amazon biome that favor increased incidence of malaria are characterized by the occupation of urban and peri-urban spaces in an uncontrolled manner; the construction of hydroelectric power plants, irrigation projects, and fishponds; the exploitation of fossil fuels, minerals, and natural gas; forest fires; deforestation; and road construction (Tadei et al., 1988, 1998, 2002, 2010; Confaloniere et al., 2014; Hahn et al., 2014). In addition to human activities, global environmental changes, such as variations in temperature, humidity, and rainfall (Campbell-Lendrum et al., 2015), can lead to the selection of resilient mosquito species with genetic adaptations for these new environmental conditions, thus enabling the selection of insects resistant to synthetic insecticides (Nkya et al., 2013; Glunt et al., 2014).

Malaria vectors and their adaptive processes, genetic background, and resilience to environmental change in the Amazon scenario are described in this study. The aspects of malaria described here directly compromise human health in the at-risk area (Betts et al., 2008; Phillips et al., 2009; Tadei et al., 2002, 2010). Covered here are aspects related to the diversity and density of vector species associated with the environment (black and white waters), resistance to chemical insecticides used in control measures, biological vector control, association of anophelines with macroinvertebrates, data on the genetic variability of vector populations, and knowledge of the structural genome, according to the transcriptome of Anopheles mosquitoes adapted to the Amazon biome.

Knowledge on the ecology and behavior of malaria vectors in the Amazonian region is essential for developing tools and strategies for controlling these vectors and, consequently, promoting a reduction in the number of cases of malaria. This knowledge allows the available tools and evaluations of the impact of the control measures used to be adjusted (Tadei et al., 1988, 1998, 2002, 2007b, 2010; Tauil, 2002; Girod et al., 2011; Hiwat \& Bretas, 2011; Confaloniere et al., 2014; Musset et al., 2014). This study correlates multiple parameters involved in the occurrence and control of malaria in the Brazilian Amazon, and it covers ecological, behavioral, and genetic aspects of the vector, in addition to anthropic and environmental factors, that are important for understanding the role and importance of $A$. darlingi in the transmission of malaria in the Amazon Basin.

\section{Amazon biome and malaria}

Malaria occurs in humans worldwide and affects approximately 219 million people, with approximately 660,000 deaths/year (WHO, 2014). In 2012, over 3.4 billion people were at risk of contracting the disease (WHO, 2015). The Americas had approximately 1.1 million cases of malaria in 2010 (with 333,528 cases in Brazil) but only 142,593 in 2014 (Ministério da Saúde, 2015, 2016). In this new scenario of environmental change, public health policy measures are insufficient for understanding and addressing the effects of climate change on the adequate control of malaria vectors (WHO, 2014). Figure 1 outlines the relationships among environmental change, anthropogenic activities, and the dynamics of malaria transmission in the Amazon ecosystem, a region where $99.8 \%$ of the malaria cases in Brazil occur and where there is an average annual temperature of $26.5^{\circ} \mathrm{C}$ and relative humidity of $88 \%$ (Ab'Saber, 2002; Silva et al., 2013).

Predictive models of the incidence of malaria have been developed, linking climate change to meteorological factors, parasite development rates, vectorial capacity, geographic distributions, and levels of economic, social and technological development. However, these models lack adequate social, political, and environmental contexts, making them ineffective as preventive measures of effective control in response to these environmental changes and vector behavior (Caminade et al., 2014; Alimi et al., 2015; Burke et al., 2015; Campbell-Lendrum et al., 2015).

The Amazon Basin is associated with factors (Fig. 1) that favor malaria transmission and make 
Fig. 1 Environmental changes and anthropogenic activities: factors that influence the parameters involved in the dynamics of malaria transmission in the Amazon ecosystem (based upon ${ }^{1}$ Wolfarth et al., 2013; ${ }^{2}$ Tadei et al., 1988, 1998, 2007a, b, 2010; ${ }^{3}$ Hahn et al., 2014)

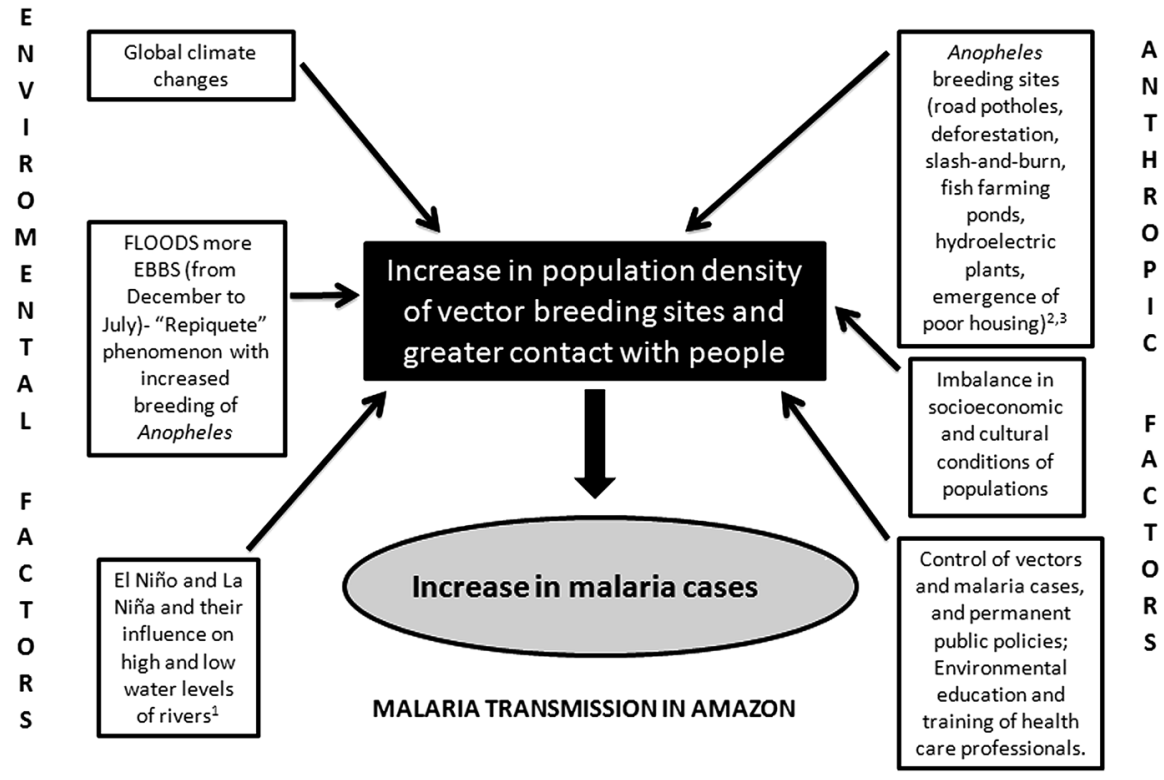

the application of control measures difficult (Tadei et al., 1988, 1998, 2002, 2007a, b, 2010; Tauil, 2002; Confaloniere, 2005; Oliveira-Ferreira et al., 2010; Girod et al., 2011; Musset et al., 2014). Accordingly, it is important to consider the physiological state of mosquito populations because nulliparous females have no epidemiological significance. In the case of malaria transmission, the physiological state becomes relevant just after the first blood meal, when the host becomes infected. It is also important to consider that oniparous females are more likely to be infected with plasmodia, depending on multiple blood meals already consumed, which may occur in infected people.

Laporta et al. (2013), using mathematical modeling from studies conducted in the community of Park Island of Cardoso, Atlantic Forest/São Paulo/Brazil, suggested that increased biodiversity could help prevent malaria outbreaks in tropical forests by altering the availability and variety of other warmblooded hosts in the forest and competition among insect vectors and nonvectors for various hosts. However, regarding A. darlingi, the main vector of malaria in the Amazon region (Girod et al., 2011), factors other than increased diversity should be taken into account, considering (for example) the diverse microhabitats of ecosystems and the degree of human occupation that changes the landscape and affects the density of $A$. darlingi in altered locations. This phenomenon can be observed in the city of Ariquemes, state of Rondônia, which was known in the 1980s and 1990s as the world capital of malaria, where transmission is currently restricted to rural areas due to environmental changes caused by the human activities which eliminate the vector's breeding sites (Tadei et al., 1998; Ministério da Saúde, 2016). Considering the dynamics of malaria transmission in the City of Manaus, the incidence of disease in the peripheral area of the city is also reduced due to the drastic changes brought about by intense human occupation in these areas, which has disrupted the A. darlingi breeding sites (Ministério da Saúde, 2016).

Therefore, the relationship between biodiversity and environmental integrity in the Amazon ecosystem depends on several factors, particularly those related to microenvironments and human intervention. It is known that ecosystems that are more preserved favor a lower diversity of the Anopheles mosquitoes implicated in spreading malaria. Drastic anthropic actions combined with marked changes in the landscape may even cause the disappearance of the mosquito $A$. darlingi in specific areas. However, if the former conditions are restored, the species may again colonize the area. Studies conducted in the Brazilian Amazon since 1985 describe different situations and the diversity of Amazonian environments with different degrees of human action (see Table 1 in Tadei et al., 1998 and Table 4 in Tadei \& Thatcher, 2000). These data demonstrate the complexity of the relationships among the natural environment, human presence, and malaria, indicating the importance of detailed studies 
to substantiate specific conclusions about each microecosystem and malaria transmission in the Amazon (Tadei et al., 1998; Tadei \& Thatcher, 2000).

Bio-ecological factors involved in malaria transmission

In the wild, during reproductive processes, females of Anopheles, among other mosquitoes, lay their eggs directly on the surface of water or on damp substrates in collections of water on the banks of rivers, streams, and deep and clear waters, such as lakes, estuaries, or large rivers (Forattini, 2002). In Amazon environments, the females also lay their eggs in flooded forests-igapós: flooded forests of black waters, such as the Negro River (Tadei et al., 1998, 2002, 2007b, 2010) and small water collections and rare breeding sites (Hiwat \& Bretas, 2011). Mosquito breeding sites show certain biophysical characteristics, such as microorganisms and different types of decaying organic matter, that are needed for the biological development of mosquitoes (Glare, 1998). Tadei et al. (2010) emphasized the importance of the occurrence of Oryza perennis (wild rice) Moench in areas of flooded forest, where the immature forms of Anopheles develop among the roots and leaves.

Anopheles darlingi, the most important species involved in malaria transmission in the Amazon Basin presents high behavioral variability (Hiwat \& Bretas, 2011), genetic plasticity (Scarpassa \& Conn, 2007; Silva et al., 2010) and resilience, adapting very well to environmental changes, particularly those caused by anthropic activities. This vector is found in areas where it did not occur previously and returns to areas where it had already been controlled (Hiwat \& Bretas, 2011), which demonstrates the great adaptability of this species. Due to these characteristics, it is difficult to evaluate the real impacts of environmental and climate changes on the population density of this vector. These associated factors make implementing effective control measures a complex task, demonstrating the need for specific strategies, such as the use of integrated management (Oliveira-Ferreira et al., 2010), to reduce the vector population and the number of malaria cases (Tadei et al., 1988, 1998, 2002, 2007, 2010; Hiwat \& Bretas, 2011).

The two great rivers of the Amazon (Solimões and Negro) have heterogeneous ecosystems that provide different breeding sites for Culicidae (Tadei et al.,
2010). Rio Solimões (white water) is geologically younger (Lopes, 1992), with high primary production of organic matter from carbon dioxide and minerals (Rios-Villamizar et al., 2016; Wolfarth et al., 2013). This environment, which includes floating macrophytes and phytoplankton, is conducive to the reproduction of Culicidae species of the genera Mansonia Blanchard, 1901 and Coquilletidia Dyar, 1905, which often show high densities and can make the environment unsuitable for human habitation (Lopes, 1992; Tadei, 1996). In contrast, the geologically older Rio Negro has acidic black water, is rich in dissolved fulvic and humic compounds, and has low productivity and electrical conductivity (Walker, 1995). This environment is conducive to the breeding of anophelines, especially A. darlingi, in areas close to human habitation (Tadei et al., 2010).

In the Amazon, the population density of $A$. darlingi responds to the hydrological cycle (Tadei et al., 2002, 2010; Girod et al., 2011; Hiwat \& Bretas, 2011; Wolfarth et al., 2013; Musset et al., 2014). This annual phenomenon influences the seasonality of species, which leads to an increase in breeding sites and intensifies human/vector contact and, hence, malaria cases. Thus, the density of anophelines is low at the beginning of the rainy season (November) and increases in April-June, concurrent with gradual increases in rainfall and river levels. At the beginning of the rainy season, vector density and the ability to transmit the malaria protozoan are low.

However, in the low-water period (July-October), the density of anophelines decreases due to the destabilization of the breeding sites, markedly reducing mosquito breeding. However, with extreme changes in global climate conditions, changes in the hydrological cycle of the Amazon region are also observed, affecting the incidence of malaria cases. This situation occurs due to abrupt increases in both the river water levels and vector density, thus exposing local populations to the malaria vector for a greater period. Tadei et al. (2002, 2007a, b, 2010) and Wolfarth et al. (2013) described this new aspect of the Amazon on the basis of studies conducted in the City of Coari and in other localities in the Amazon.

Thus, considering these major environmental changes that occur annually in the Amazon and have a direct relation to the hydrological cycle in the region, it is of fundamental importance to study the annual variation of the density of $A$. darlingi. It is also 
important to consider two aspects that are intrinsically related to malaria control: (1) analyses of the physiological state of $A$. darlingi populations in areas where measures are implemented and (2) installations of screens on doors and windows of homes and the use of mosquito nets impregnated with insecticides over beds and hammocks (Martins-Campos et al., 2012).

Considering the physiological state of $A$. darlingi females is important for determining periods of increased exposure to oniparous females, when there is greater likelihood of transmission of Plasmodium. In A. darlingi, these females are more common during later hours; however, there are studies that show, in more detail, the effects of continuous aerospatial applications on oniparous females. Previous works have shown that thermonebulization works by reducing the frequency of oniparous females. However, more data are required to reach significant conclusions regarding this important parameter of control in areas of intense malaria transmission (Tadei et al., 2010; Ministério da Saúde, 2015).

It is also relevant to consider the efficacy of control measures related to the protection of the population provided by the use of screens on doors and windows of homes and insecticide-impregnated raffia curtains used in miners huts, as a primary barrier, blocking the entrance of the vector and reducing human/vector contact (Figueiredo et al., 1998). The concomitant use of insecticide-impregnated mosquito nets over beds represents a second protective barrier to contact with the vector (Martins-Campos et al., 2012), ensuring a better quality of life for exposed populations in at-risk areas (Santos et al., 1999).

Laporta et al. (2013) conducted studies involving mathematical models of human activities, climate change, and malaria relations both currently and in 2070. The authors predicted that there will be a decrease in populations of $A$. darlingi favoring the Albitarsis complex because of the drier climate and increased anthropogenic activities by 2070 . In contrast, Alimi et al. (2015), also using mathematical modeling, investigated the distribution of $A$. darling $i$ and Anopheles nuneztovari Galbadon, 1940 in relation to climate change and deforestation between 2010 and 2070 in northern South America. The authors predicted interference by these factors in the distribution of these two species but proposed new technologies and reducing deforestation as a means of eradicating malaria. For the complex ecosystem of the Amazon, it is critical to consider local influences on each microregion related to $A$. darlingi, human activities and intensified current climatic influences because the pulses of flows and ebbs interfere with the diversity and density of anophelines in relation to behavioral patterns in specific areas, thus changing the dynamics of malaria transmission (Tadei et al., 1998, 2002, 2007b, 2010).

In 22 locations in the Amazon in a variety of environments with and without anthropogenic activities, 11,895 anophelines were collected, including 5,784 A. darlingi, 3,308 A. nuneztovari and 1,904 Anopheles albitarsis Lynch: Arribálzaga, 1878 specimens (see Table 1 in Tadei \& Thatcher, 2000). Seven of the 33 known species in the region were found to be infected by Plasmodium using ELISA detection, including $A$. albitarsis and A. nuneztovari, coadjuvant species of $A$. darlingi in the transmission of the disease. Malaria transmission in these areas is directly associated with the presence of $A$. darlingi. In terms of infection by Plasmodium falciparum Welch, 1897, A. darlingi displayed the highest infectivity index, 1:193, and for mixed infection [Plasmodium vivax (Grassi \& Feletti), 1890 and P. falciparum], an index of 19 positive suspensions. A. nuneztovari also showed a high infectivity index, 1:150, and an index of 10 positive suspensions for mixed infection; in $A$. albitarsis, these values were 1:136 and 6, respectively (see Table 2 in Tadei et al., 1998). There is a need to map areas where $A$. darlingi and species of the $A$. albitarsis complex are found to identify endemic areas. There is an intrinsic complexity between $A$. darling $i$ and malaria transmission in many ecosystems both in endemic and nonendemic areas, according to the current literature (Tadei et al., 1998, 2010; Tadei \& Thatcher, 2000; Girod et al., 2011; Barros et al., 2012; Araújo et al., 2014; Martins et al., 2015). Thus, there is a need for detailed studies involving different ecosystems in relation to $A$. darlingi and environmental change.

Seventeen stations in the Amazon along the rivers of the region were monitored monthly on the basis of data from hydrological monitoring of the Amazon Basin by the National Water Agency of Brazil (ANA), Geological Services of Brazil (CPRM), and the Amazon Protection System (SIPAM). The data from this monitoring showed that the conditions of the headwaters of the Amazon Basin differ markedly from the central part of the basin. The behavior of water 
affects the environment and breeding conditions, which influence the frequency of the occurrence of Anopheles species in these regions. Data previously obtained in the Amazon show that A. darlingi is the most susceptible to climate change, water regime, and anthropogenic activities, which favor or reduce the number of breeding sites. Water rise or fall is accompanied by a disruption of breeding sites, reducing the food supply for the larvae and reducing the population density of $A$. darlingi (Tadei et al., 1991, 1998, 2002; Laporta et al., 2013). Anopheles triannulatus Neiva \& Pinto, 1922, sensu lato, A. nuneztovari sensu lato, and the Albitarsis complex have higher resilience, which is the capacity to adapt to conditions of climate and environmental changes (Tadei et al., 1991, 1983; Tadei \& Thatcher, 2000).

The phenomenon of the "repiquete" and its role in malaria transmission

Variations in river water levels are constant in the Amazon region, where many suitable basins for mosquito breeding can be found. However, sudden and irregular breaks in water level variation can occur in periods of both flooding and receding, regionally called "repiquete," the duration of which is variable. Wolfarth et al. (2013) defined "repiquete" as a variation in the water level of rivers, as opposed to the general tendency of the hydrological regime. It should be noted that "repiquete" can occur during both high waters and receding river levels, showing variation from year to year. These authors emphasize that the duration of "repiquete" is extremely variable, from 9 to 56 days, and can be classified as less than 30 days or more than 30 but fewer than 60 days. These hydrological phenomena may be associated with climate change processes, the effects of which result in increased cases of malaria at uncharacteristic times (Tadei et al., 1998, 2010). The distributions of $A$. darlingi and $A$. albitarsis therefore fluctuate according to these variations in river levels under natural conditions. These results demonstrate significant positive correlations between cases of malaria and temperature, precipitation, and water levels (Barros \& Honório, 2007). Similarly, Wolfarth et al. (2013) noted that increases in water levels in recent years also reflect the malaria transmission cycle.
A "repiquete" associated with an increased density of A. darlingi was recorded in Lago de Coari in 2007, when it was observed that the river level rose in December/January, followed by a short "summer" with approximately 30 days of intense sunlight, where the effect of a "repiquete" was observed. Consequently, anophelines reproduced explosively and communities were exposed to the vector at a high density, resulting in an increase in malaria cases around the Coari/Manaus gas pipeline (Tadei et al., 2010).

Another study conducted by Wolfarth et al. (2013) analyzed the water level using daily data to determine the specific days of the occurrence of the "repiquete" phenomenon in four municipalities of Amazonas, namely Codajás, Coari, Manacapuru, and Manaus Cities. Also included were the epidemiological results of malaria, which exhibited a heterogeneous distribution between these municipalities. There were variations in transmission over the years studied (2003-2009), even in periods influenced by climatic effects, such as El Niño in 2003, a severe drought in 2005 and La Niña in 2009. The city of Manacapuru had the highest malaria transmission rate, and Coari was second. There was an increase in cases of the disease in the dry season, mainly starting in August, with more concentrated records during droughts. The highest rates of malaria cases appeared, on average, 1-1.5 months after the "repiquete." The results showed positive and significant correlations between malaria cases and temperature, and precipitation and water level.

Floods in malaria transmission

The Amazon biome is governed by a natural system of water, with ebbs and flows that annually modify the environment and determine the living conditions in this region. In the central Amazon, the rains usually begin in November, when the river waters begin to rise, flooding forests, producing numerous breeding sites and initiating a new cycle of malaria transmission. The waters rise gradually and high river water levels (approximately $20 \mathrm{~m}$ ) usually occur in June. In May/June, rains are markedly reduced, causing the onset of the dry season, which lasts until October. The decrease in river waters begins in June/July and extends until September, featuring the ebbing of the rainy season. However, this natural water cycle is 
currently undergoing extreme modifications, probably resulting from environmental and climate changes being recorded in the Amazon (Tadei et al., 1998, 2002, 2010).

Floods in the Amazon biome have occurred more extensively in recent years (Wolfarth et al., 2013). According to estimates in the Amazon, 36 cities were affected by floods in 2015. Of this total, 34 were in an emergency situation, although the water levels had started to fall, with Humaita $\left(7^{\circ} 30^{\prime} 22^{\prime \prime} \mathrm{S}, 63^{\circ} 1^{\prime} 38^{\prime \prime} \mathrm{W}\right)$ and Boca do Acre, located in the confluence of the Rio Acre and Rio Purus (950 km from Manaus, the capital of Amazonas), still in a state of emergency in 2015, according to the State Civil Defense.

According to Tadei et al. (2007a), Coari was surprised by an unusual summer, which caused a $300-500 \%$ increase in the density of $A$. darling $i$ in the region. The main lake in the city had higher water levels than usual, with waters penetrating the forest and forming a flooded forest, producing an ideal environment for mosquito breeding.

Published data reveal that the increase in water depth formed by floods favors the contact of $A$. darling $i$ with the inhabitants because the breeding sites are closer to the houses along the riverbanks, forming microhabitats where the larvae develop, thereby completing the transmission cycle of malaria human/parasite/vector, as noted by Tadei et al. (1998, 2002, 2007b, 2010).

Fish farming ponds and biological vector control

The Western Amazon region has natural characteristics favorable for the development of fish farming: clayey yellow latosol soil, annual rainfall approximately $2,400 \mathrm{~mm}$, average temperature of $26.5^{\circ} \mathrm{C}$, $88 \%$ relative humidity, and average daily sunshine of 5.4 h (Ab'Saber, 2002; Silva et al., 2013). With these favorable conditions, along with government encouragement, there has been a $62 \%$ growth in the issuance of licenses for fish farmers, with a current output of 15,000 tons/year, and the projection is 100,000 tons of fish/year in about one decade (SEPROR, 2014).

Studies show that fishponds become breeding sites of $A$. darlingi due to the black water, and marginal vegetation added to the fish feed replenished daily, promoting conditions for oviposition of Anopheles females and larval development. Unlike the natural conditions in the Amazon, fishponds are a permanent breeding site of $A$. darlingi in the vicinity of Manaus. This phenomenon occurs because water supply tanks are not influenced by the pulse of flood and ebb tides, keeping the vector breeding conditions at high levels throughout the year. Likewise, climate changes do not affect the stability of the tanks because they are a closed system. Therefore, fishponds must be continuously monitored to prevent the reproduction of the vector and prevent the transmission of malaria (Tadei et al., 2005, 2007a, b; Rodrigues et al., 2008, 2013).

Control measures in these environments are viable and should be considered, and the primary functions of the aquatic environment should be preserved. Bacterial biological control is a measure that attempts to eliminate pests and disease vectors through biotic agents that are pathogenic, antagonistic, and/or lethal. The use of bacterial entomopathogens, such as Bacillus sphaericus Neide, 1904 (Bs) and Bacillus thuringiensis israelensis Berliner, 1915 (Bti), is an alternative to conventional control measures against Anopheles larvae that considers the preservation of the environment (De Barjac, 1990). Field tests conducted in the central Amazon using Bti and Bs found greater effectiveness in black water than white water due to the presence of Chromobacterium violaceum (Schröter, 1872) releasing violacein into the water, which has a photobiological action on bacteria (Rodrigues et al., 2013). Studies on biological control in fishponds have noted an abundance of $A$. darlingi, corresponding to $54 \%$ of larvae collected. Other species present in the ponds were Anopheles braziliensis Chagas, 1907, A. triannulatus, $A$. nuneztovari, and A. albitarsis, the last with low abundance. The reduction in larval percentage indicated a rapid effect of Bs within $24 \mathrm{~h}$ after its application (Tadei et al., 2007b; Rodrigues et al., 2008).

Bacterial biological control was also evaluated for possible effects on macroinvertebrates, which coexist with mosquitoes. Associated aquatic insects play important roles in nutrient cycling, as bioindicators, and in the diet of several fishes in the regional economy. An estimate of these insects was made in four fishponds around Manaus, and a total of 12,495 specimens of aquatic insects were found, including some important indicators of water quality. After 15 days of Bs application, approximately $100 \%$ of aquatic insects recovered their preapplication abundance levels (Sampaio et al., 2005). A regression analysis of time intervals using the readings as 
independent variable against richness (jackknife order 1) $\left(r^{2}=0.04\right)$ and Shannon diversity $\left(H^{\prime}\right)$ $\left(r^{2}=0.002\right)$ in a study carried out by Ferreira et al. (2015) in fishponds indicated that these variables were not affected by the application of Bs. Thus, the results showed no effect of the larvicide on the general insects present in fishponds.

\section{Genetics of malaria vectors}

Population genetics and functional genome of Anopheles darlingi

Indicators of changes in vector behavior can be observed in genetic studies that characterize and map structures in the RNA, DNA, and chromosomes of mosquito populations influenced by changes in the Amazon biome.

The wide geographic distribution of $A$. darlingi, especially in the Amazon, as well as significant differences among populations based on studies of polytene chromosomes (Tadei \& Santos, 1982; Tadei et al., 1982), isoenzymes (Steiner et al., 1982; Santos et al., 1999), and behavior (Rosa-Freitas et al., 1992; Charlwood, 1996) led to the hypothesis that $A$. darlingi is a species complex. However, this hypothesis was rejected by Manguin et al. (1999) in a study of samples from different parts of its distribution range using morphology, isoenzymes, random amplified of polymorphic DNA (RAPD), and internal spacing of the internal transcribed spacer 2 (ITS2) gene. Later, other studies based on the mitochondrial COI gene (Mirabello \& Conn, 2006) and DNA microsatellites (Conn et al., 2006) found significant differences in Central America and part of Colombia as well as in the Amazon region.

Considering these controversies and the importance of $A$. darlingi, Lima et al. (2010) constructed a microsatellite DNA library and characterized 24 microsatellite polymorphic loci with a total of 184 alleles for a population in Coari (Amazonas, Brazil). Most repeats for loci were dinucleotides (56.5\%), where TG/CA was the most common (42.8\%). A total of 270 alleles were obtained, of which 24 loci were analyzed: 12 with regard to genetic variability in two populations of the Amazon (Table 1), one from Coari and the other from São Gabriel da Cachoeira, located $622.76 \mathrm{~km}$ away. Regarding the population of São
Gabriel da Cachoeira, the study examined 96 alleles, with an average of seven alleles per locus and significant deviation from Hardy-Weinberg equilibrium for three loci (Ada06, Ada23 and Ada27), due to an excess of homozygotes, indicated by the inbreeding coefficient $\left(F_{\text {IS }}\right)$ values of these loci $(0.423,0.434$ and 0.527).

Linkage disequilibrium was not observed between the loci for any of the populations studied. This species showed high genetic variability in these populations that revealed by the observed and expected heterozygosities $\left(H_{\mathrm{O}}=0.650\right.$ and $\left.H_{\mathrm{E}}=0.728\right)$, but it showed low genetic differentiation $\left(F_{\mathrm{ST}}=0.028\right)$ and high genetic similarity $(D=0.0962)$ between populations. The high rate of gene flow $\left(N_{\mathrm{m}}=9.507\right)$ found between populations of Coari and São Gabriel da Cachoeira, measured by the number of migrant individuals and based on $F_{\mathrm{ST}}$ values, indicated that they could be considered a single panmictic population, whose genetic distance showed no relationship to the geographical distance between these populations.

The Coari locality is characterized by constantly implemented environmental changes due to construction of the Petrobras (Brazilian Oil Company) pipeline. These changes have increased the mosquito density and malaria cases in the region, leading to intense use of synthetic insecticides to control malaria. In contrast, the population of A. darlingi in São Gabriel da Cachoeira, situated in the upper Rio Negro, Amazonas State, has not suffered these environmental changes, but malaria is present. Intensive use of chemical insecticides has selected populations resistant to these compounds, and the resistance phenomenon has been observed in more than 50 Anopheles species (Hemingway \& Ranson, 2000; Dong, 2007).

Another example of the above phenomenon was noted by Scarpassa \& Conn (2007). Populations of $A$. darlingi in Coari (AM) and Porto Velho (RO), separated by a large geographical distance, showed low genetic differentiation and large gene flow ( $F_{\mathrm{ST}}=0.030$ and 0.024 , and $N_{\mathrm{m}}=16.2$ and 20.0, respectively). These studies show the genetic plasticity of populations of this mosquito, which ensures survival conditions despite the imposed environmental changes.

Recently, two studies obtained samples from populations of A. darlingi collected in North, Southeast, and Central-west Brazil, based on a morphological 


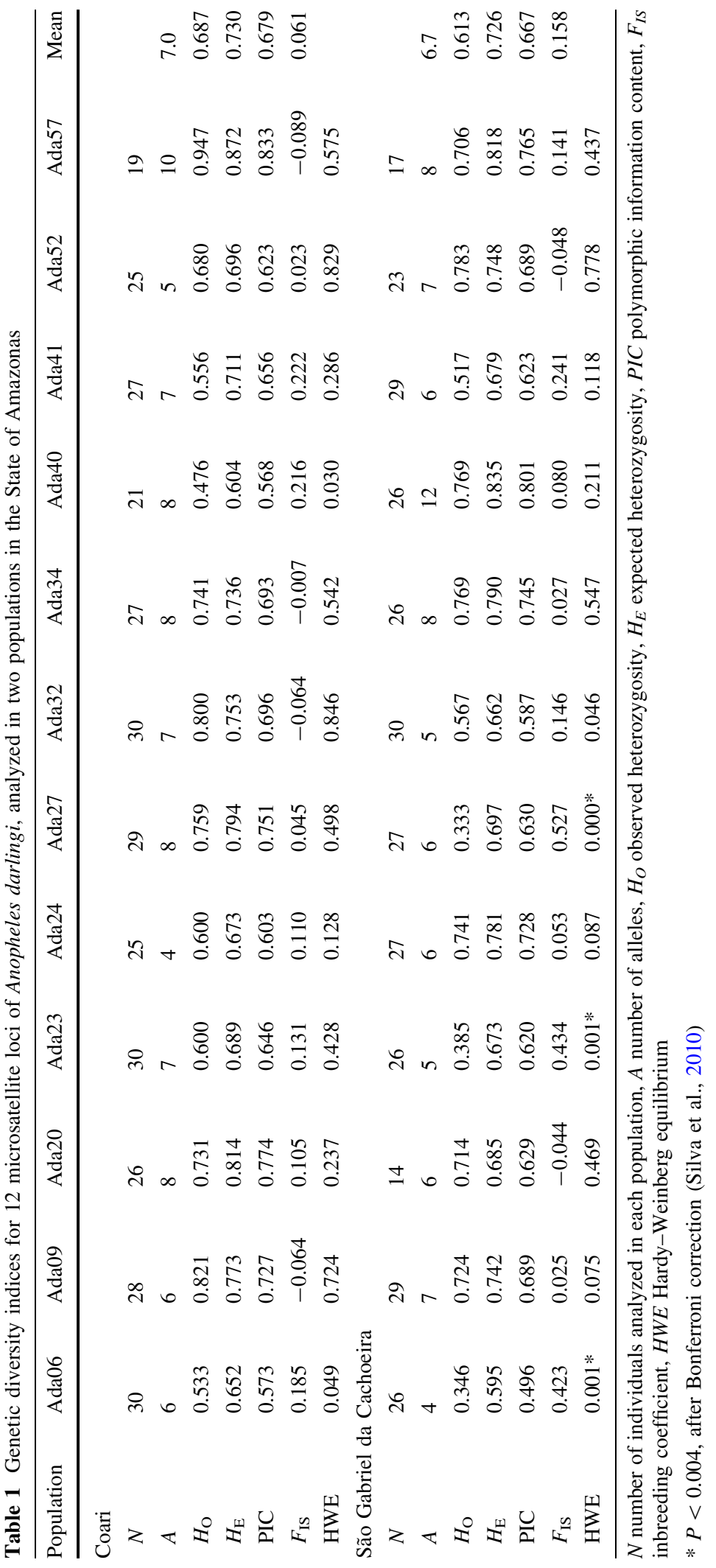


analysis of the wing (Motoki et al., 2012) and SNP molecular markers (Emerson et al., 2015). No significant differences were found between these populations at the interspecific level.

The hematophagic behavior of $A$. darlingi occurs in the intra-, peri-, and extradomicile areas, relevant parameters in studies of Anopheles populations because they show the patterns of malaria transmission mechanisms (Tadei et al., 1993, 1998). A study by Silva et al. (2010) that used molecular markers patterns of genetic variability to examine intra-, peri, and extradomicile hematophagic behavior in two populations of $A$. darlingi of Coari and Manaus (Amazonas) revealed high genetic variability in these populations.

In the population of $A$. darlingi of Coari, the percentages of polymorphic loci $(P)$ and heterozygosity $\left(H_{\mathrm{E}}\right)$ values ranged from 77.63 to $84.86 \%$ and 0.2851 to 0.3069 , respectively, with the highest genetic variability detected in the intradomicile area subpopulations and the lowest in the peridomicile area. The population of $A$. darlingi of Manaus showed genetic variability similar to that of Coari $(P=$ $75-78.94 \%$ and $\left.H_{\mathrm{E}}=0.2732-0.2741\right)$, where greater genetic variability was also detected indoors (Table 2 ). The Chi-square data $\left(\chi^{2}=695.89, \mathrm{df}=304, P<\right.$ $0.001)$ and $F_{\mathrm{ST}}$ values $\left(F_{\mathrm{ST}}=0.0775 \pm 0.0072\right)$ between Coari and Manaus were significant, indicating microgeographic structuring due to a reduction in gene flow (Silva et al., 2010).

These results can be interpreted as a response to selection pressure from insecticides, with residual product remaining on the walls of homes. These data also showed that the intradomicile subpopulations had the highest genetic variability in both Coari and
Manaus. The greater genetic variability observed in these subpopulations of $A$. darlingi revealed greater genetic plasticity, which may give this species greater adaptability to environmental changes and/or malaria control measures.

Studies of populations of $A$. darlingi in Venezuela, for example, showed refractory malaria in that country due to the marked exophilic behavior of the species in restricted areas of geographical distribution (Gabaldón, 1978; Rojas et al., 1992). This behavior is considered the main cause of the ineffectiveness of pesticides sprayed inside homes in that country.

In the Amazon, as reported by Tadei et al. (1993, 1998) and Akhavan et al. (1999), insecticides are sprayed inside and outside homes to control the mosquitoes that transmit malaria. The insecticides sprayed outside disperse rapidly, whereas those sprayed inside remain longer, impregnated in the walls of homes. Thus, to exploit and adapt to these altered environments, a population may need higher genetic plasticity, which is conferred by high genetic variability. Under these conditions, the population is able to adjust its physiological activity in a way that suits the habitat. Thus, genetic plasticity and/or adaptation can facilitate the establishment and growth of the population under new habitat conditions (Dobzhansky, 1970; Orr, 2005).

The environmental changes and selection pressure due to human activities have altered the interactions among vectors, malaria parasites, and humans (Tadei et al., 1998). However, A. darlingi lacks genetic and evolutionary studies to assist in addressing unanswered basic questions about the vector-parasite and its interactions with the human host.

Table 2 Estimate of genetic variability in populations of Anopheles darlingi in Coari and Manaus (AM), captured in the intra-, peri-, and extradomicile areas, based on RAPD analysis

\begin{tabular}{|c|c|c|c|c|}
\hline \multirow[t]{2}{*}{ Population } & \multirow{2}{*}{$\begin{array}{l}\text { Mean number of samples } \\
\text { per loci }\end{array}$} & \multirow{2}{*}{$\begin{array}{l}\text { Percentage of polymorphic } \\
\text { loci }^{\mathrm{a}}\end{array}$} & \multicolumn{2}{|c|}{ Mean heterozygosity } \\
\hline & & & Observed & Expected $^{\mathrm{b}}$ \\
\hline Coari intradomicile & 20 & 84.86 & 0.3012 & 0.3069 \\
\hline Coari peridomicile & 20 & 79.60 & 0.2916 & 0.2960 \\
\hline Coari extradomicile & 10 & 77.63 & 0.2634 & 0.2851 \\
\hline Manaus intradomicile & 25 & 78.94 & 0.2695 & 0.2741 \\
\hline Manaus peridomicile & 25 & 75.00 & 0.2683 & 0.2732 \\
\hline
\end{tabular}

${ }^{\text {a }}$ Frequency of the most common allele, equal to or less than 0.95 (Ayala, 1982)

b Nei's unbiased estimate (Nei,1978) (Silva et al., 2010) 
Several mosquito genomes have been published. Anopheles gambiae Giles, 1902 (subfamily Anophelinae), the vector of malaria in Africa, has 278, 253,050 bp, according to Holt et al. (2002); Aedes aegypti Linnaeus, 1762 (subfamily Culicinae), transmitter of Dengue, Zika, and Chikungunya virus, has 1.38 Gbp (Nene et al., 2007); and Culex quinquefasciatus Say, 1823 (subfamily Culicinae), vector of arbovirus, has 579,042,118 bp (http://cquinquefascia tus.vectorbase.org/Culex_quinquefasciatus/Info/Index). A. darlingi has a completely assembled genome (Marinotti et al., 2013). The mean nuclear genome size is $173.92(\mathrm{Mb})$, and the value for $A$. darlingi (female) was estimated to be $2 C=0.41 \mathrm{pg}$ or $1 C=200.49 \mathrm{Mbp}$ (Marinotti et al., 2013). The genome of this species has 5.5 billion nucleotides, or "letters" of DNA, but some of those "letters" are not translated into proteins. In addition, there is no transcriptome analysis (RNAseq libraries) for A. darlingi.

We performed a transcriptome analysis of pooled larvae and emerged adults from Coari Municipality, Amazonas State, Brazil (Rafael et al., 2008, 2010). In this study, specimens of $A$. darlingi from Coari revealed 568 unigenes that were homologous to ESTs of A. gambiae, A. aegypti, C. quinquefasciatus, and other organisms. The ESTs of $A$. darling $i$ aligned with gene sequences of $A$. gambiae (61\%, 349 unigenes), $A$. aegypti (10\%, 55 unigenes), C. quinquefasciatus ( $8 \%$, 49 unigenes), and other organisms (11\%, 55 unigenes). The sharing of ESTs with A. gambiae was expected, considering that both species are of the same genus, Anopheles (Rafael et al., 2008, 2010). This work may assist in understanding the aspects correlated with differential accumulation-specific gene expression and may reveal molecular targets for novel vector control and pathogen transmission blocking, in addition to comparing the complete $A$. darlingi genome to the complex A. gambiae genome.

However, the finding of shared sequences of $A$. darlingi with $A$. aegypti and $C$. quinquefasciatus suggests a more distant evolutionary relationship, corroborating previous studies indicating that the time of divergence between anophelines and culicids occurred approximately 120 million years ago and that the radiation of the species within the genus Anopheles occurred approximately 79 million years ago (Moreno et al., 2010).

Anopheles darlingi ESTs were used for in silico mapping in A. gambiae to compare the locations of these sequences in the genomes of the two species (Bridi, 2009). The ESTs of A. darlingi and A. gambiae showed regions of similarity in their genomes. Clusters and singlets of $A$. darling $i$ were hybridized to chromosomes of A. gambiae: X chromosome, 13 clusters; 2R arm, 64 clusters; 2L arm, 40 clusters; 3R arm, 45 clusters; and $3 \mathrm{~L}$ arm, 34 clusters; they comprised 793 chromosomal regions. Both species are vectors of malaria, with A. gambiae of the Old World and A. darlingi of the New World, and they share common aspects and habits, such as morphology and biting behavior; the latter is characterized by a preference for feeding on human blood (Tadei et al., 1998, 2007b, 2010).

Despite the high population density of $A$. darlingi, control measures with synthetic insecticides are not effective in some endemic regions due to the heavy use and cumulative effects of pesticides on this mosquito. However, in recent decades, new alternatives involving molecular markers have contributed to the knowledge of the biology of the genetic and evolutionary mechanisms of mosquitoes. The GST family of metabolic detoxification genes has been a good indicator of mosquito resistance to deltamethrin (Balkew et al., 2010). In our study, the GST gene family of the transcriptome of A. darlingi was mapped in silico to the left arm of polytene chromosome 3 of $A$. gambiae, and the sigma class GST (KC890767) was physically mapped to section $3 \mathrm{~A}$ of the polytene $\mathrm{X}$ chromosome of A. darlingi (Fig. 2).

These data suggest chromosomal rearrangement in paracentric inversions, which has been extensively documented in Anopheles species (Tadei \& Santos, 1982; Tadei et al., 1982; Coluzzi et al., 2002; Michel et al., 2005; Rafael et al., 2010). Additionally, they provide an understanding of the polymorphism and frequency of existing chromosomal inversions in $A$. darling $i$ in different locations of the Amazon, where $A$. darlingi transmits malaria.

The GST gene family obtained from cDNA libraries of $A$. darlingi was used to characterize quantitative gene expression by qRT-PCR in this mosquito from Coari, Amazonas, subjected to bioassays with deltamethrin at different concentrations (Naice, 2010). The authors performed bioassays with deltamethrin at $0.025,0.003125$, and $0.0015625 \%$, which caused mortality in A. darlingi at levels of 46 , 20 , and $25 \%$, respectively, compared with control individuals. These researchers used cDNAs of these 


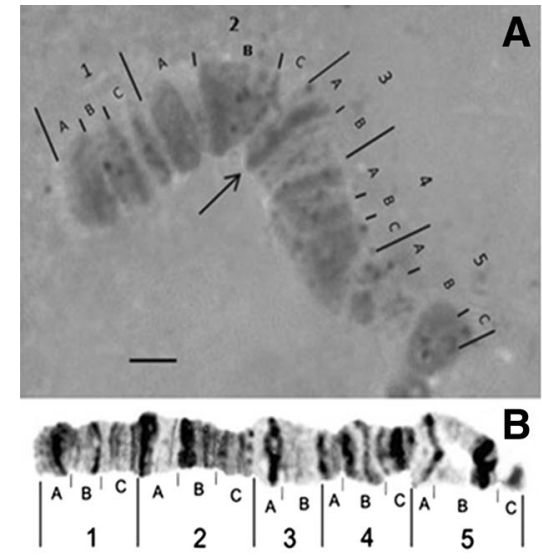

Fig. 2 In situ hybridization mapping of the sigma class GST (KC890767) gene to the polytene chromosomes of A. darlingi. A Polytene $\mathrm{X}$ chromosome. The arrow indicates the location of hybridization on Section 3A, B photomap indicating divisions

individuals amplified from the GST and GAPDH genes and analyzed them using the comparative $C_{\mathrm{T}}$ $\left(\Delta \Delta C_{\mathrm{T}}\right)$ method. A difference in GST gene expression occurred in $A$. darlingi treated with 0.025 and $0.003125 \%$ deltamethrin, with gene expression found to be 50 and $33 \%$ greater, respectively, at $1 \mathrm{~h}$ than at $8 \mathrm{~h}$. These results showed that this gene is an excellent marker of deltamethrin resistance compared with GSTs of other Anopheles species, considering the low mortality shown with deltamethrin, i.e., 8.75 and $46.25 \%$ at 1 and $8 \mathrm{~h}$, respectively.

In addition, Azevedo-Junior et al. (2014) studied the orthology relationship between sigma class GST (KC890767) of the transcriptome of $A$. darlingi and the GSTS1_1 gene by reciprocal best Blast hit with the Blast2go program. The sigma class GST gene of $A$. darling $i$ was analyzed due to the importance of this gene in detoxification mechanisms because this mosquito is under synthetic insecticide selection pressure, similar to various mosquitoes of epidemiologic importance. The authors suggested that the phylogenetic relationships among GST genes of mosquitoes are of great importance for understanding the functions of gene products in response to insecticide selection pressure.

The sigma class GST (KC890767) of A. darlingi was used for phylogenetic analyses to elucidate the GST gene base composition of the most recent common ancestor between GST genes of A. darlingi, A. gambiae, A. aegypti, and C. quinquefasciatus (Azevedo-Junior et al., 2014). These authors

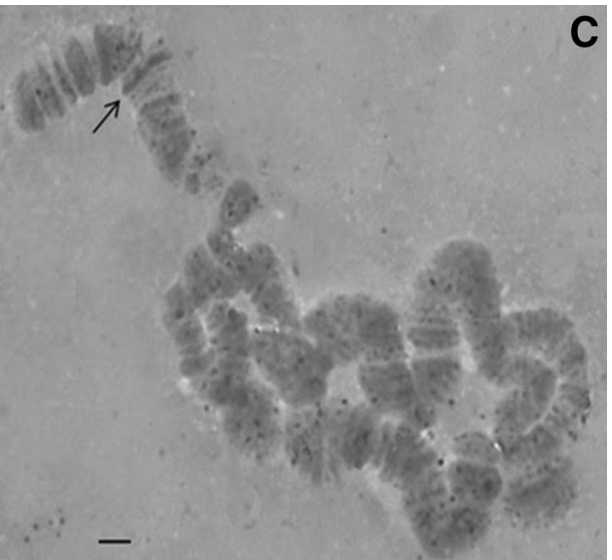

and sections of the polytene $\mathrm{X}$ chromosome of A. darlingi (Rafael et al., 2010), and $\mathbf{C}$ full chromosome core. The arrow indicates the location of hybridization. Bar $10 \mu \mathrm{m}$

constructed a phylogenetic tree of GST (KC890767) of $A$. darlingi using the neighbor-joining program, which analyzes sequences by comparing amino acid residues 1 by 1 and uses mathematical calculations to evaluate these residue mutation rates, generating scores for each amino acid, then calculating and organizing the sequence branch in the phylogenetic tree. As a form of validation, the results of the analysis were also evaluated by Blast obtained by the Blast2go program. The phylogenetic analysis confirmed the confidence levels on the tree nodes that separated the sigma class GST (KC890767) of A. darlingi and GST genes of other mosquito species, as shown in Fig. 3.

The authors suggested that the phylogeny of the sigma class GST (KC890767) of A. darlingi is

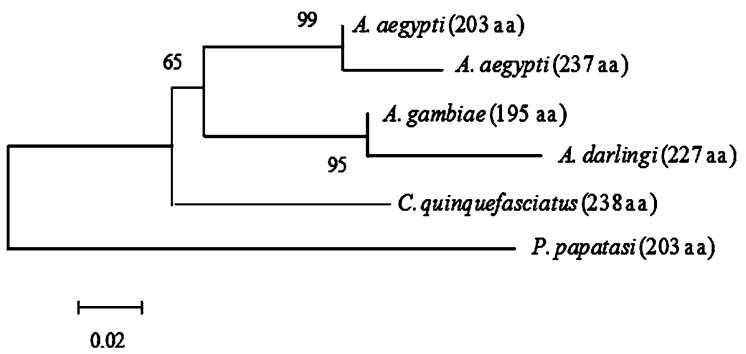

Fig. 3 Comparison between the sigma class GST (KC890767) of Anopheles darlingi and GST genes of Anopheles gambiae, Aedes aegypti, Culex quinquefasciatus, and Phlebotomus papatasi (Scopoli, 1786) (outgroup) by global alignment using Clustal W and a phylogenetic tree constructed by neighbor joining (Saitou \& Nei, 1987). The bar indicates $2 \%$ amino acid divergence (based on Azevedo-Junior et al., 2014) 
conserved in evolutionary terms, showing grouping of the GST genes of A. gambiae, A. aegypti, and $C$. quinquefasciatus (Azevedo-Junior et al., 2014) and grouping of the sigma class GST (KC890767) of $A$. darlingi and the GSTS1_1 gene of A. gambiae on the same branch.

\section{Conclusion}

The Amazon biome is the largest forest on the planet and is responsible for regulating various environmental components at the global level, but it is not immune to climate change. Water movements and "repiquete" complemented by various human activities in this biome have favored $A$. darlingi with regard to increases in breeding sites, the proximity of this vector to river communities, and the resilience of the species to new environmental scenarios, thereby fostering conditions for increases in malaria. The understanding and mitigation of these environmental changes and knowledge of the bio-ecology of vectors in these new scenarios require sustainable public policies for the development of the Amazon, together with permanent means of integrated management of vectors aimed at the control of endemic diseases.

The high density of $A$. darlingi contributes to the increase in malaria in endemic areas, such as in the cities of Coari and Manaus, where the intensive use of chemical insecticides in the control of malaria vectors in this region has been steady. Relatively little is still known about the relation between genetic mechanisms and the dynamics of malaria transmission of this mosquito. Still, a study of genetic diversity (by RAPD) in populations of $A$. darlingi in Coari revealed higher polymorphism rates in intradomicile populations, where mosquitoes enter homes for their blood meal. This higher polymorphism can be an adaptive strategy in response to selection pressure by the intensive use of insecticides in these environments.

The similarity between the GST gene families of $A$. darlingi and A. gambiae (by in silico hybridization) was a useful tool for further biological and evolutionary trait studies. In A. darlingi we found an increased level of sigma class GST gene expression by enhanced detoxification effect of GST. The phylogenetic data grouped the sigma class GST (KC890767) of $A$. darlingi and the GSTS1_1 gene of A. gambiae on the same branch, suggesting that the GST genes of the two species evolved from a common GST gene and are evolutionarily closer than GST gene of A. aegypti and C. quinquefasciatus.

Understanding the population dynamics of the functional genome of $A$. darlingi associated with bio-ecology, global environmental change, human activities, resistance to chemical insecticides, and alternative control of vectors associated with the use of immature forms with macroinvertebrates, among other permanent public policies, is needed to achieve a better quality of life for human populations in the Amazon region.

Malaria control requires the understanding of preventive measures by human populations exposed to mosquitoes in endemic areas. Furthermore, it is important that the actions implemented consider the physiological state of the mosquito populations because the greatest risk of exposure to the vector is in later times. Thus, it is crucial that people are protected at these times, which is provided by the use of traditional technologies, such as mosquito nets, but considering the new generation of mosquito nets impregnated with insecticides. Therefore, awareness of the people of this behavioral tool will be the main focus for reducing the incidence of malaria, with consequent decreased use of chemical insecticides in control programs.

Acknowledgments We thank the technical malaria and dengue laboratory and health workers. The Foundation for Health Surveillance-FVS and Health State and Municipal Departments of Manaus and Coari. This work is supported by the Rede MaláriaNational Counsel of Technological and Scientific Development (CNPq) Award Number 555665/2009, ADAPTA/CNPq: 5739 76/2008-2, Rede Bionorte/CNPq: 554317/2010-9, Pro-Amazônia/ CAPES - 3319/2013 and PIATAM V-Brazilian Innovation Agency (FINEP), 01.11.0107.00.

\section{References}

Ab'Saber, A. N., 2002. Bases para o estudo dos ecossistemas da Amazônia brasileira [available on internet at http://www. scielo.br/pdf/ea/v16n45/v16n45a02]. Accessed 20 February 2015 .

Akhavan, D. P., P. Musgrove, A. Abrantes \& R. d' A. Gusmão, 1999. Cost-effective malaria control in Brazil cost-effectiveness of a malaria control program in the Amazon Basin of Brazil, 1988-96. Social Science and Medicine 49: 1385-1389.

Alimi, T. O., D. O. Fuller, W. A. Qualls, S. V. Herrera, M. Arevalo-Herrera, M. L. Quinones, M. V. G. Lacerda \& J. C. Beier, 2015. Predicting potential ranges of primary 
malaria vectors and malaria in northern South America based on projected changes in climate, land cover and human population. Parasites and Vectors 8: 431.

Araújo, R., A. M. Silva, E. C. Souza Filho \& E. Luz, 2014. Composição da fauna de Anopheles (Diptera: Culicidae) da Reserva Indígena do Ocoy, foco ativo de malária no município de São Miguel do Iguaçu, Paraná (Brasil). Acta Biológica Paranaense 43: 85-112.

Ayala, F. J., 1982. Population and Evolutionary Genetics. A primer. Benjamin/Cummings Publishing Press, California.

Azevedo-Junior, G. M., G. M. Guimaraes, L. C. Bridi, K. C. Ohse, R. Vicentin, W. P. Tadei \& M. S. Rafael, 2014. Phylogenetic analysis of the GST family in Anopheles (Nyssorhynchus) darlingi. Acta Tropica 136: 27-31.

Balkew, M., M. Ibrahim, L. L. Koekemoer, B. D. Brooke, H. Engers, A. Aseffa, T. Gebre-Michael \& I. Elhassen, 2010. Insecticide resistance in Anopheles arabiensis (Diptera: Culicidae) from villages in central, northern and south west Ethiopia and detection of kdr mutation. Parasites and Vectors 3: 40.

Barros, F. S. M. \& N. A. Honório, 2007. Man biting rate seasonal variation of malaria vectors in Roraima, Brazil. Memórias do Instituto Oswaldo Cruz 102: 299-302.

Barros, F. S. M., W. P. Tadei, M. E. Arruda \& N. A. Honório, 2012. On the use of classic epidemiological formulae for estimating the intensity of endemic malaria transmission by vectors in the Amazon. Neotropical Entomology. doi:10.1007/s13744-012-0065-5.

Betts, R., M. Sanderson, S. Woodward, Y. Malhi, T. Roberts \& R. A. Betts, 2008. Effects of large-scale Amazon forest degradation on climate and air quality through fluxes of carbon dioxide, water, energy, mineral dust and isoprene. Philosophical Transaction of the Royal Society of London: Biological Sciences. doi:10.1098/rstb.2007.0027.

Bridi, L. C., 2009. Mapeamento físico de genes expressos de Anopheles darlingi Root, 1926 e sua análise in silico em Anopheles gambiae Giles, 1902 (Diptera: Culicidae). MSc Thesis, National Institute of Amazonian Research.

Burke, M., S. M. Hsiang \& E. Miguel, 2015. Global non-linear effect of temperature on economic production. Nature. doi:10.1038/nature15725.

Caminade, C., S. Kovats, J. Rocklov, A. M. Tompkins, A. P. Morse, F. J. Colon-Gonzalez, H. Stenlund, P. Martens \& S. J. Lloyd, 2014. Impact of climate change on global malaria distribution. Proceedings of the National Academy of Sciences of USA 111: 3286-3291.

Campbell-Lendrum, D., L. Manga, M. Bagayoko \& J. Sommerfeld, 2015. Climate change and vector-borne diseases: What are the implications for public health research and policy? Philosophical Transaction of the Royal Society of London: Biological Sciences 370: 1665.

Charlwood, J. D., 1996. Biological variation in Anopheles darlingi Root. Memórias do Instituto Oswaldo Cruz 91: 391-398.

Coluzzi, M., A. Sabatini, A. DellaTorre, M. A. DiDeco \& V. Petrarca, 2002. A polytene chromosome analysis of the Anopheles gambiae species complex. Science 298: 1415-1418.

Confaloniere, U. E. C., 2005. Saúde na Amazônia: um modelo conceitual para análise de paisagem e doenças. Estudos Avançados. doi:10.1590/S0103-40142005000100014.
Confaloniere, U. E. C., C. Margonari \& A. F. Quintão, 2014. Environmental change and the dynamics of parasitic diseases in the Amazon. Acta Tropica 129: 33-41.

Conn, J. E., J. H. Vineis, J. P. Bollback, D. Y. Onyabe, R. C. Wilkerson \& M. M. Póvoa, 2006. Population structure of the malaria vector Anopheles darlingi in an endemic region of eastern Amazonian Brazil. American Journal of Tropical Medicine and Hygiene 74: 798-806.

De Barjac, H., 1990. Classification of Bacillus sphaericus strains and comparative toxicity to mosquito larvae. In De Barjac, H. \& D. J. Sutherland (eds), Bacterial Control of Mosquitoes and Black Flies: Biochemistry, Genetics and Applications of Bacillus thuringiensis israelensis and Bacillus sphaericus. Rutgers University Press, New Brunswick: 228-236.

Dobzhansky, T. H., 1970. Genetics of the Evolutionary Process. Columbia University Press, New York.

Dong, K., 2007. Insect sodium channels and insecticide resistance. Invertebrate Neuroscience. doi:10.1007/s10158006-0036-9.

Emerson, K. J., J. E. Conn, E. S. Bergo, M. A. Randel \& M. A. M. Sallum, 2015. Brazilian Anopheles darlingi Root (Diptera: Culicidae) clusters by major biogeographical region. PLoS One. doi:10.1371/journal.pone.0130773.

Ferreira, F. A. S., A. N. Arcos, R. T. M. Sampaio, I. B. Rodrigues \& W. P. Tadei, 2015. Effect of Bacillus sphaericus Neide, 1904 on Anopheles (Diptera: Culicidae) and associated insect fauna in fish ponds in the Amazon. Revista Brasileira de Entomologia. doi:10.1016/j.rbe.2015.03.013.

Figueiredo, R. M. P., W. P. Tadei \& B. D. Thatcher, 1998. The control of anopheline mosquitos by the spraying of Deltamethrin on raffia curtain used in miner's huts in areas endemic for malaria. Revista do Instituto de Medicina Tropical de São Paulo 40: 107-111.

Forattini, O. P., 2002. Culicidologia Médica. Identificação, Biologia Epidemiologia. EDUSP Press, São Paulo.

Gabaldón, A., 1978. What can and cannot be achieved with conventional anti-malaria measures. American Journal of Tropical Medicine and Hygiene 27: 653-658.

Girod, R., E. Roux, F. Berger, A. Stefani, P. Gaborit, R. Carinci, J. Issaly, B. Carme \& I. Dusfour, 2011. Unravelling the relationships between Anopheles darlingi (Diptera: Culicidae) densities, environmental factors and malaria incidence: understanding the variable patterns of malarial transmission in French Guiana (South America). Annals of Tropical Medicine and Parasitology 105: 107-122.

Glare, T. R. \& M. Callaghan, 1998. Environmental and Health Impacts of Bacillus thuringiensis israelensis. Report for the Ministry of Health: 57.

Glunt, K. D., K. P. Paaijmans, A. F. Read \& M. B. Thomas, 2014. Environmental temperatures significantly change the impact of insecticides measured using WHOPES protocols. Malaria Journal. doi:10.1186/1475-2875-13-350.

Hahn, M. B., R. E. Gangnon, C. Barcellos, G. P. Asner \& J. A. Patz, 2014. Influence of deforestation, logging, and fire on malaria in the Brazilian Amazon. PLoS One. doi:10. 1371/journal.pone.0085725.

Hemingway, J. \& H. Ranson, 2000. Insecticide resistance in insect vectors of human disease. Annual Review of Entomology 45: 371-391. 
Hiwat, H. \& G. Bretas, 2011. Ecology of Anopheles darlingi Root with respect to vector importance: a review. Parasites and Vectors. doi:10.1186/1756-3305-4-177.

Holt, R. A., G. M. Subramanian, A. Halpern, G. G. Sutton, R. Charlab, D. R. Nusskern, P. Wincker, A. G. Clark, J. M. Ribeiro, R. Wides, S. L. Salzberg, B. Loftus, M. Yandell, W. H. Majoros, D. B. Rusch, Z. Lai, C. L. Kraft, J. F. Abril, V. Anthouard, P. Arensburger, P. W. Atkinson, H. Baden, V. Berardinis, D. Baldwin, V. Benes, J. Biedler, C. Blass, B. D. Bolanos, M. Barnstead, S. Cai, A. Center, K. Chatuverdi, G. K. Christophides, M. A. Chrystal, M. Clamp, A. Cravchik, V. Curwen, A. Dana, A. Delcher, I. Dew, C. A. Evans, M. Flanigan, A. Grundschober-Freimoser, L. Friedli, Z. Gu, P. Guan, R. Guigo, M. E. Hillenmeyer, S. L. Hladun, J. R. Hogan, Y. S. Hong, J. Hoover, O. Jaillon, Z. Ke, C. Kodira, E. Kokoza, A. Koutsos, I. Letunic, A. Levitsky, Y. Liang, J. J. Lin, N. F. Lobo, J. R. Lopez, J. A. Malek, T. C. McIntosh, S. Meister, J. Miller, C. Mobarry, E. Mongin, S. D. Murphy, D. A. O'Brochta, C. Pfannkoch, R. Qi, M. A. Regier, K. Remington, H. Shao, M. V. Sharakhova, C. D. Sitter, J. Shetty, T. J. Smith, R. Strong, J. Sun, D. Thomasova, L. Q. Ton, P. Topalis, Z. Tu, M. F. Unger, B. Walenz, A. Wang, J. Wang, M. Wang, X. Wang, K. J. Woodford, J. R. Wortman, M. Wu, A. Yao, E. M. Zdobnov, H. Zhang, Q. Zhao, S. Zhao, S. C. Zhu, I. Zhimulev, M. Coluzzi, D. A. Torre, C. W. Roth, C. Louis, F. Kalush, R. J. Mural, E. W. Myers, M. D. Adams, H. O. Smith, S. Broder, M. J. Gardner, C. M. Fraser, E. Birne, P. Bork, P. T. Brey, J. C. Venter, J. Weissenbach, F. C. Kafatos, F. H. Collins \& S. L. Hoffman, 2002. The genome sequence of the malaria mosquito Anopheles gambiae. Science 298: 129-149.

Laporta, G. Z., P. P. I. Lopez, R. A. Kraenkel, R. M. Coutinho \& M. A. M. Sallum, 2013. Biodiversity can help prevent malaria outbreaks in tropical forests. PLoS Neglected Tropical Diseases. doi:10.1371/journal.pntd.0002139.

Lima, G. N., J. S. Batista, K. M. Formiga, F. W. Cidade, M. S. Rafael, W. P. Tadei \& J. M. M. Santos, 2010. New 24 polymorphic DNA microsatellite loci for the major malaria vector Anopheles darlingi and transpecies amplification with another anophelines. Conservation Genetics Resources. doi:10.1007/s12686-010-9237-y.

Lopes, U. B., 1992. Aspectos físicos, químicos e ecológicos das misturas naturais de águas físico-quimicamente diferentes, na Amazônia. PhD Thesis, National Institute of Amazonian Research.

Manguin, S., R. C. Wilkerson, J. E. Conn, Y. Rubio-Palis, J. A. Danoff-Burg \& D. Roberts, 1999. Population structure of the primary malaria vector in South America, Anopheles darlingi, using isozyme, random amplified polymorphic DNA, internal transcribed spacer 2, and morphologic markers. American Journal of Tropical Medicine and Hygiene 60: 364-376.

Marinotti, O., G. C. A. Cerqueira, L. G. P. Ferro, M. I. T. Loreto, E. L. D. S. Zaha, A. Teixeira, S. M. R. Wespiser, A. R. A. Silva, A. Schlindwein, A. D. Pacheco, A. C. L. Silva, A. L. D. C. D. Graveley, B. R. Walenz, B. P. Lima, B. D. A. Ribeiro, C. A. G. Nunes-Silva, C. G. Carvalho, C. R. Soares, C. M. D. A. Menezes, C. B. A. Matiolli, C. Caffrey, D. Araujo, D. A. M. Oliveira, D. M. Golenbock, D. Grisard, E. C. Fantinatti-Garboggini, F. Carvalho, F.
M. Barcellos, F. G. Prodocimi, F. May, G. Azevedo Junior, G. M. D. Guimaraes, G. M. Goldman, G. H. Padilha, I. Q. M. Batista, J. D. S. Ferro, J. A. Ribeiro, J. M. C. Fietto, J. L. R. Dabbas, K. M. Cerdeira, L. Agnez-Lima, L. F. Brocchi, M. Carvalho, M. O. Teixeira, M. D. M. Diniz, M. D. M. Maia, M. H. S. Goldman, M. P. Cruz Schneider, M. S. S. Felipe, M. Hungria, M. F. Nicolas, M. Pereira, M. A. Montes, M. E. Cantao, M. Vincentz, M. S. Rafael, N. Silverman, P. H. Stoco, R. C. Souza, R. Vicentini, R. T. Gazzinelli, R. D. O. Neves, R. Silva, S. Astolfi-Filho, T. E. F. Maciel, T. P. Urmenyi, W. P. Tadei, E. P. Camargo \& A. T. R. Vasconcelos, 2013. The genome of Anopheles darlingi, the main neotropical malaria vector. Nucleic Acids Research 41: 7387-7400.

Martins, R., G. F. Monteiro, F. M. da Costa \& Y. Antonini, 2015. First record of Anopheles darlingi Root (Diptera, Culicidae) in the Volta Grande Environmental Reserve, Conceição das Alagoas Municipality, Minas Gerais, Brazil [available on internet at http://www.periodico.ebras.bio.br/ ojs/index.php/ebras/article/view/ebrasilis.v8i1.474]. Accessed 3 November 2015.

Martins-Campos, K. M., W. D. Pinheiro, S. Vítor-Silva, A. M. Siqueira, G. C. Melo, Í. C. Rodrigues, N. F. Fé, M. G. V. Barbosa, W. P. Tadei, C. Guinovart, Q. Bassat, P. L. Alonso, M. V. G. Lacerda \& W. M. Monteiro, 2012. Integrated vector management targeting Anopheles darlingi populations decreases malaria incidence in an unstable transmission area, in the rural Brazilian Amazon. Malaria Journal. doi:10.1186/1475-2875-11-351.

Michel, A. P., W. M. Guelbeogo, O. Grushko, B. J. Schemerhorn, M. Kern \& M. B. Willard, 2005. Molecular differentiation between chromosomally defined incipient species of Anopheles funestus. Insect Molecular Biology 14: 375-387.

Miles, L., A. Grainger \& O. Phillips, 2004. The impact of global climate change on tropical forest biodiversity in Amazonia. Global Ecology and Biogeography. doi:10.1111/j.1466822X.00105.

Ministério da Saúde, 2015. Guia para gestão local do controle da Malária - Controle vetorial [available on internet at http:// bvsms.saude.gov.br/bvs/publicacoes/guia_gestao_local_ controle_vetorial.pdf]. Accessed 2 May 2015.

Ministério da Saúde, 2016. Malária: situação epidemiológica [available on internet at http://portalsaude.saude.gov.br/ index.php/o-ministerio/principal/leia-mais-o-ministerio/ 662-secretaria-svs/vigilancia-de-a-a-z/malaria/11346-situacaoepidemiologica-dados]. Accessed 2 August 2016.

Ministério do Meio Ambiente, 2010. Programa Áreas protegidas da Amazônia: ARPA - Biodiversidade [available on internet at http://www.programaarpa.gov.br/wp-content/uploads/20 12/10/arpaBiodiversidade]. Accessed 2 April 2016.

Mirabello, L. \& J. E. Conn, 2006. Molecular population genetics of the malaria vector Anopheles darlingi in Central and South America. Heredity 96: 311-321.

Moreno, M., O. Marinotti, J. Krzywinski, W. P. Tadei, A. A. James, L. N. Achee \& E. J. Conn, 2010. Complete mtDNA genomes of Anopheles darlingi and an approach to anopheline divergence time. Malaria Journal. doi:10.1186/ 1475-2875-9-127.

Motoki, M. T., L. Suesdek, E. S. Bergo \& M. A. M. Sallum, 2012. Wing geometry of Anopheles darlingi Root (Diptera: 
Culicidae) in five major Brazilian ecoregions. Infection, Genetics and Evolution 12: 1246-1252.

Musset, L., S. Pelleau, R. Girord, V. Ardillon, L. Carvalho, I. Dusfour, M. S. M. Gomes, F. Djossou \& E. Legrand, 2014. Malaria on the Guiana Shield: a review of the situation in French Guiana. Memórias do Instituto Oswaldo Cruz. doi:10.1590/0074-0276140031.

Naice, M. V., 2010. Expressão do gene de resistência da Glutationa S-Transferase (GST) em Anopheles darlingi Root, 1926 (Diptera; Culicidae) em condições de estresse químico, Coari, Amazonas. MSc Thesis, National Institute of Amazonian Research.

Nei, M. 1978. Estimation of average heterozigosity and genetic distance from a small number of individuals. Genetics 89 : 583-590.

Nene, V., J. R. Wortman, D. Lawson, B. Haas, C. Kodira, Z. J. Tu, B. Loftus, Z. Xi, K. Megy, M. Grabherr, Q. Ren, E. M. Zdobnov, N. F. Lobo, K. S. Campbell, S. E. Brown, M. F. Bonaldo, J. Zhu, S. P. Sinkins, D. G. Hogenkamp, P. Amedeo, P. Arensburger, P. W. Atkinson, S. Bidwell, J. Biedler, E. Birney, R. V. Bruggner, J. Costas, M. R. Coy, J. Crabtree, M. Crawford, B. DeBruyn, D. DeCaprio, K. Eiglmeier, E. Eisenstadt, H. El-Dorry, W. M. Gelbart, S. L. Gomes, M. Hammond, L. I. Hannick, J. R. Hogan, M. H. Holmes, D. Jaffe, J. S. Johnston, R. C. Kennedy, H. Koo, R. Kravitz, E. V. Kriventseva, D. Kulp, K. LaButti, E. Lee, S. Li, D. D. Lovin, C. Mao, E. Mauceli, C. F. M. Menck, J. R. Miller, P. Montgomery, A. Mori, A. L. Nascimento, H. F. Naveira, C. Nusbaum, S. O'Leary, J. Orvis, M. Pertea, H. Quesneville, K. R. Reidenbach, W. Y. Rogers, C. H. Roth, J. R. Schneider, M. Schatz, M. Shumway, M. Stanke, E. O. Stinson, J. M. C. Tubio, J. P. VanZee, S. Verjovski-Almeida, D. Werner, O. White, S. Wyder, Q. Zeng, Q. Zhao, Y. Zhao, C. A. Hill, A. S. Raikhel, M. B. Soares, D. L. Knudson, N. H. Lee, J. Galagan, S. L. Salzberg, I. T. Paulsen, G. Dimopoulos, F. H. Collins, B. Birren, C. M. Fraser-Liggett \& D. W. Severson, 2007. Genome sequence of Aedes aegypti, a major arbovirus vector. Science 316: 1718-1723.

Nkya, T. E., I. W. AkhouayriKisinza \& J.-P. David, 2013. Impact of environment on mosquito response to pyrethroid insecticides: facts, evidences and prospects. Insect Biochemistry and Molecular Biology 43: 407-416.

Nobre, C. A., M. D. Oyama, G. S. Oliveira, J. A. Marengo \& E. Salati, 2004. Impact of climate change scenarios for 2100 on the biomes of South America. First International CLIVAR Conference, Baltimore, USA.

Oliveira-Ferreira, J., M. V. G. Lacerda, P. Brasil, J. L. B. Ladislau, P. L. Tauil \& C. T. Daniel-Ribeiro, 2010. Malaria in Brazil: an overview. Malaria Journal. doi:10.1186/14752875-9-115.

Orr, H. A., 2005. The genetic theory of adaptation: a brief history. Nature Reviews Genetics. doi:10.1038/nrg1523.

Phillips, O. L., L. E. O. C. Aragão, S. L. Lewis, J. B. Fisher, J. Lloyd, G. López-González, Y. Malhi, A. Monteagudo, J. Peacock, C. A. Quesada, G. Heijden, S. Almeida, I. Amaral, L. Arroyo, G. Aymard, T. R. Baker, O. Bánki, L. Blanc, D. Bonal, P. Brando, J. Chave, A. C. A. Oliveira, N. D. Cardozo, C. I. Czimczik, T. R. Feldpausch, M. A. Freitas, E. Gloor, N. Higuchi, E. Jiménez, G. Lloyd, P. Meir, C. Mendoza, A. Morel, D. A. Neill, D. Nepstad, S. Patiño,
M. C. Peñuela, A. Prieto, F. Ramírez, M. Schwarz, J. Silva, M. Silveira, A. S. Thomas, H. Steege, J. Stropp, R. Vásquez, P. Zelazowski, E. A. Dávila, S. Andelman, A. Andrade, K. Chao, T. Erwin, A. Di Fiore, E. Honorio, H. Keeling, T. J. Killeen, W. F. Laurance, A. P. Cruz, N. C. A. Pitman, P. N. Vargas, H. Ramírez-Angulo, A. Rudas, R. Salamão, N. Silva, J. Terborgh \& A. Torres-Lezama, 2009. Drought sensitivity of the Amazon rainforest. Science 323: 1344-1347.

Rafael, M. S., C. G. Nunes-Silva, G. M. Azevedo Junior, G. M. Guimarães, L. C. Bridi, E. N. Assunção, S. Astolfi-Filho \& W. P. Tadei, 2008. Banco de Genes Expressos de Anopheles darlingi adulto (Diptera; Culicidae), Coari, Amazonas [available on internet at http://web2.sbg.org.br/ congress/sbg2008/pdfs2008/25834]. Accessed 30 July 2016.

Rafael, M. S., L. C. Bridi, I. P. Santos Junior, K. C. NunezSouza, J. M. M. Santos \& W. P. Tadei, 2010. Vetores da malária na Amazônia: do cariótipo ao genoma funcional. In Bermudez, E. G. C., B. R. Teles \& R. Ale-Rocha (eds), Entomologia na Amazônia Brasileira. National Institute of Amazonian Research, Manaus: 303-314.

Rios-Villamizar, E. A., M. T. F. Piedade \& W. J. Junk, 2016. Tipologias de águas em áres úmidas da bacia Amazonica: Uma revisão enfatizando a classificação dos rios e Igarapés. In Ferreira, S. J. F., M. L. Silva \& D. Pascoaloto (eds), Amazônia das Aguas: Qualidade, Ecologia e Educação Ambiental. Valer Press, Manaus: 175-191.

Rodrigues, I. B., W. P. Tadei, R. L. C. Santos, S. Santos \& J. B. Baggio, 2008. Controle da malária: eficácia de formulados de Bacillus sphaericus 2362 contra larvas de espécies de Anopheles em criadouros artificiais - tanques de piscicultura e criadouros de olaria [available on internet at http:// www.revistas.ufg.br/iptsp/article/view/5047]. Accessed 2 May 2015.

Rodrigues, I. B., W. P. Tadei, J. M. C. S. Dias \& C. A. P. Lima, 2013. Atividade Larvicida de Bacillus sphaericus 2362 contra Anopheles sp. (Diptera, Culicidae) em rios do Amazonas, Brasil. Sociedade Entomológica do Brasil. doi:10.14295/BA.v8.0.95.

Rojas, E., E. Brown, C. Rosas \& J. V. Scorza, 1992. Populations of larvae of Anopheles spp. in natural breeding sites in Western Venezuela, an area of refractory malaria. Revista de Saúde Pública de São Paulo. doi:10.1590/S003489101992000500007.

Rosa-Freitas, M. G., G. Broomfield, A. Priestman, P. J. M. Milligan, H. Momen \& D. H. Molyneux, 1992. Cuticular hydrocarbons, isoenzymes and behavior of three populations of Anopheles darlingi from Brazil. Journal of American Mosquito Control Association 8: 357-366.

Saitou, N. \& M. Nei, 1987. The neighbor-joining method: a new method for reconstructing phylogenetic trees. Molecular Biology and Evolution 4: 406-425.

Sampaio, R. T. M., I. B. Rodrigues, W. P. Tadei, L. S. Castro \& F. M. Cauper, 2005. Composição da entomofauna aquática sob efeito do Bacillus sphaericus 2362 em tanques de piscicultura na Amazônia [available on internet at http://www.bionorte. org.br/banco-de-competencias/producaodetalhes.htm?idp= 355620]. Accessed 2 May 2015.

Santos, J. M. M., J. A. Lobo, W. P. Tadei \& E. P. B. Contel, 1999. Intrapopulational genetic differentiation in 
Anopheles (N.) darlingi Root, 1926 (Diptera: Culicidae) in the Amazon region. Genetics and Molecular Biology. doi:10.1590/S1415-47571999000300007.

Scarpassa, V. M. \& J. E. Conn, 2007. Population genetic structure of the major malaria vector Anopheles darlingi (Diptera: Culicidae) from the Brazilian Amazon, using microsatellite markers. Memórias do Instituto Oswaldo Cruz 102: 319-327.

Scholze, M., W. Knorr, N. Arnell \& I. C. Prentice, 2005. A climate change risk analysis for world ecosystems. Proceedings of the National Academy of Sciences of USA. doi:10.1073/pnas.0601816103.

SEPROR, 2014. Piscicultores buscam adotar tecnologia da Embrapa que pode triplicar produção de peixe no Amazonas [available on internet at https://www.embrapa.br/ web/mobile/noticias/-/noticia/1472703/piscicultoresbuscam-adotar-tecnologia-que-pode-triplicar-producaode-peixe-no-am]. Accessed 18 February 2014.

Silva, A. P. B., W. P. Tadei \& J. M. M. Santos, 2010. Variabilidade genética em populações de Anopheles darlingi (Diptera: Culicidae) e relação ao comportamento da atividade de picar, analisada por RAPD. Acta Amazonica. doi:10.1590/S0044-59672010000300019.

Silva, A. D. R., R. B. Santos, A. M. M. S. Bruno \& E. C. Soares, 2013. Cultivo de tambaqui em canais de abastecimento sob diferentes densidades de peixes. Acta Amazônica. doi:10. 1590/S0044-59672013000400014.

Siqueira, M. F. \& A. T. Peterson, 2003. Consequences of global climate change for geographic distributions of cerrado tree species. Biota Neotropica. doi:10.1590/S1676-0603200 3000200005.

Steiner, W. W. M., S. K. Narang, J. B. Kitzmiller \& D. L. Swofford, 1982. Genetic divergence and evolution in neotropical Anopheles (subgenus Nyssorhynchus). In Steiner, W. W. M., W. J. K. Tabachnick, S. Rai \& S. K. Narang (eds), Recent Developments Genetics Insects Disease Vectors. Stipes Publishing, Champaign: 523-551.

Tadei, W. P., 1996. O gênero Mansonia (Diptera, Culicidae) e a proliferação de mosquitos na Usina Hidrelétrica de Tucuruí. In Magalhães, S. B., R. C. Brito \& E. R. Castro (eds), Energia na Amazônia. Editora Belém, Belém: 311-318.

Tadei, W. P. \& J. M. M. Santos, 1982. Biologia de anofelinos Amazônicos. VII. Estudo da variação de frequências das inversões cromossômicas de Anopheles darlingi, Root 1926 (Diptera, Culicidae) [available on internet at https:// acta.inpa.gov.br/fasciculos/12-4/PDF/v12n4a09]. Accessed 2 May 2015.

Tadei, W. P. \& B. D. Thatcher, 2000. Malaria vectors in the Brazilian Amazon: Anopheles of the subgenus Nyssorhynchus. Revista do Instituto de Medicina Tropical de São Paulo. doi:10.1590/S0036-46652000000200005.

Tadei, W. P., J. M. M. Santos \& M. G. Rabbani, 1982. Biologia de anofelinos Amazônicos. V. Polimorfismo cromossômico de Anopheles darlingi, Root 1926 (Diptera, Culicidae) [available on internet at https://acta.inpa.gov.br/fasciculos/12-2/PDF/ v12n2a18]. Accessed 2 May 2015.

Tadei, W. P., B. M. Mascarenhas \& M. G. Podestá, 1983. Biologia de anofelinos amazônicos. VIII. Conhecimento sobre a distribuição de espécies de Anopheles na região de Tucuruí-Marabá (Pará) [available on internet at https://
acta.inpa.gov.br/fasciculos/13-1/PDF/v13n1a09]. Accessed 2 May 2015.

Tadei, W. P., J. M. M. Santos, W. L. S. Costa \& V. M. Scarpassa, 1988. Biologia de anofelinos amazônicos. XII. Ocorrência de espécies de Anopheles, dinâmica da transmissão e controle da malária na zona urbana de Ariquemes (Rondônia). Revista Instituto de Medicina Tropical de São Paulo 30: 221-251.

Tadei, W. P., V. M. Scarpassa \& I. B. Rodrigues, 1991. Evoluções das populações de Anopheles e Mansonia na área de influencia da Usina Hidrelétrica de Tucurui (Pará). Ciência e Cultura 43: 639-640.

Tadei, W. P., J. M. M. Santos, V. M. Scarpassa \& I. B. Rodrigues, 1993. Incidência, distribuição e aspectos ecológicos de espécies de Anopheles (Diptera: Culicidae), em regiões naturais e sob impacto ambiental da Amazônia Brasileira. In Ferreira, E. J. G., G. M. Santos, E. L. M. Leão \& L. A. Oliveira (eds), Bases científicas para estratégias de preservação e desenvolvimento da Amazônia. Instituto Nacional de Pesquisas da Amazônia, Manaus: 167-196.

Tadei, W. P., B. D. Thatcher, J. M. M. Santos, V. M. Scarpassa, I. B. Rodrigues \& M. S. Rafael, 1998. Ecologic observations on anopheline vectors of malaria in the Brazilian Amazon. American Journal of Tropical Medicine and Hygiene 59: 325-335.

Tadei, W. P., I. B. Rodrigues, J. M. M. Santos, M. S. Rafael, C. A. P. Lima, S. Costa, W. C. M. Terrazas \& E. O. Figueiredo, 2002. Malária e ecossistemas amazônicos: dinâmica de transmissão, vetores e controle. Annals of the Seminário de apresentação dos resultados dos projetos de pesquisa dirigida - PPDG7 MCT- Ministry of Science and Technology 01: 1-7.

Tadei, W. P., R. S. Cordeiro, G. R. O. Lima, R. C. Pinto, J. M. M. Santos, I. B. Rodrigues, M. S. Rafael, C. A. P. Lima \& W. C. M. Terrazas, 2005. Controle da malária em Manaus: tanques de piscicultura, proliferação de anofelinos e monitoramento [available on internet at http://www.sbpenet.org.br/ livro/57ra/programas/SENIOR/RESUMOS/resumo_3726. html].

Tadei, W. P., R. A. Passos, I. B. Rodrigues, J. M. M. Santos \& M. S. Rafael, 2007a. Indicadores entomológicos e o risco de transmissão de malária na área de abrangência do projeto PIATAM. In Cavalcante, K. V., A. A. F. Rivas \& C. E. C. Freitas (eds), Indicadores Socioambientais e Atributos de Referência para o trecho Urucu-Coari-Manaus. Rio Solimões, Manaus: 65-74.

Tadei, W. P., I. B. Rodrigues, J. M. M. Santos, M. S. Rafael, R. A. Passos, F. M. Costa, R. C. Pinto \& A. E. M. Oliveira, 2007b. O papel da entomologia no controle da malária. Annals of the Revista Brasileira de Medicina Tropical 40: 22-26.

Tadei, W. P., J. M. M. Santos, I. B. Rodrigues \& M. S. Rafael, 2010. Malária e Dengue na Amazônia: vetores e estratégias de controle. In Subsecretaria de Coordenação das Unidades de Pesquisas, MCT (ed.), Pesquisa Científica e Tecnológica em Saúde. MCT, Ministry of Science and Technology, Brasília: 113-125.

Tauil, P. L., 2002. Avaliação de uma nova estratégia de controle da malária na Amazônia Brasileira. PhD Thesis, University of Brasilia.

Thomas, C. D., A. Cameron, R. E. Green, M. Bakkenes, L. J. Beaumont, Y. C. Collinggham, B. F. N. Erasmus, M. 
F. Siqueira, A. Grainger, L. Hannah, L. Hughes, B. Huntley, A. S. Van Jaarsveld, G. F. Midgley, L. Miles, M. A. Ortega-Huerta, A. T. Peterson, O. L. Phillips \& S. E. Williams, 2004. Extinction risk from climate change. Nature. doi:10.1038/nature02121.

United Nations Framework Convention of Climate Change (UNFCCC), 2007 [available on internet at http://unfccc.int/ resource/docs/2007/cop13/eng/06a01]. Accessed March 2015.

Walker, I., 1995. Amazonian streams and small rivers. In Tundisi, J. G., C. E. Bicudo \& T. Matsumura-Tundisi (eds), Limnology in Brazil. ABC/SBL, Rio de Janeiro: 167-193.

Wolfarth, B. R., N. Filizola, W. P. Tadei \& L. Durieux, 2013. Epidemiological analysis of malaria and its relationships with hydrological variables in four municipalities of the State of Amazonas, Brazil. Hydrological Sciences Journal. doi:10.1080/02626667.2013.831977.

World Health Organization (WHO), 2014. Campaigns [available on internet at http://www.who.int/campaigns/malariaday/2013/en/index.html]. Accessed 2 May 2015.

World Health Organization (WHO), 2015. World Malaria Report [available on internet at http://www.who.int/ malaria/publications/world-malaria-report-2015/report/en/ ]. Accessed 2 March 2016.

World Wide Fund (WWF), 2006. Climate Change Impacts in the Amazon - Review of Scientific Literature [available on internet at http://assets.panda.org/downloads/amazon_cc_ impacts_lit_review_final_2.pdf]. Accessed 2 May 2015. 